\title{
Characterization of Grapevine Rugose Wood Disease Sources from Italy
}

\author{
R. Credi, Istituto di Patologia Vegetale, Università degli Studi di Bologna, Via Filippo Re 8, 40126 Bologna, Italy
}

\begin{abstract}
Credi, R. 1997. Characterization of grapevine rugose wood disease sources from Italy. Plant Dis. 81:1288-1292.

A collection of 27 sources of grapevine rugose wood (RW) disease from a viticultural region in northern Italy was analyzed by graft-inoculating vines of three selective Vitis indicators $(V$. rupestris cv. St. George, V. berlandieri $\times$ V. riparia cv. Kober $5 \mathrm{BB}$, and hybrid cv. LN 33). On the basis of stem reactivity, different groups were identified among the selected RW inoculum sources: nine isolates induced pitting only on cv. St. George, whereas four induced grooving only on cv. Kober 5BB. These two groups were classified as isolates of rupestris stem pitting and Kober stem grooving. Three of the remaining isolates induced wood abnormalities on cvs. LN 33 and Kober 5BB, seven induced wood abnormalities on cvs. St. George and Kober 5BB, and four induced symptoms on all three indicators. These groups may represent RW sources with various disease combinations. RW-affected grapevine clones used as inoculum sources also were tested for virus infections by enzyme-linked immunosorbent assay (ELISA). ELISA revealed the presence of grapevine fleck virus, grapevine leafroll-associated closterovirus 1 and 3, and grapevine trichovirus A. These viruses infected most of the selected RW sources. However, eight of the latter were ELISA-negative. The findings are discussed, and the biological and etiological complexity of the RW phenomena in grapevine is confirmed.
\end{abstract}

Viruses and virus-like pathogenic agents, transmitted and perpetuated by vegetative propagation, cause economically serious diseases in grapevines. One of the most important of these diseases is rugose wood (RW), which occurs worldwide and is especially common in Italy. RW is a generic term adopted to designate a group of distinct disorders, mainly characterized by the development of pitting and grooving in the woody cylinder. The diseases generally are found on Vitis vinifera L. cultivars in a latent state, and symptoms usually do not appear until bud scions from diseased donor vines are grafted onto certain American rootstocks, when they adversely affect growth and yield $(16,20)$.

On the basis of the latest information, four RW syndromes may be identified by graft-inoculation of healthy indicator vines $(13,15,16,19)$ : rupestris stem pitting (RSP), with distinctive symptoms on $V$. rupestris Sheele 'St. George'; Kober stem grooving (KSG), so termed because of the reaction on rootstock cv. Kober 5BB ( $V$. berlandieri Planch. $\times$ V. riparia Michx.); LN 33 stem grooving (LNSG), which only induces symptoms on indicator hybrid cv. LN 33 (Couderc $1613 \times$ Thompson Seedless); and corky bark (CB), which is expressed in $V$. rupestris and cv. LN 33. The RW etiology

Corresponding author: R. Credi

E-mail: rcredi@pop.agrsci.unibo.it

Accepted for publication 30 July 1997.

Publication no. D-1997-0916-01R

(C) 1997 The American Phytopathological Society has not been established, but flexuous filamentous viral particles have been found in vines with wood deformities $(1,6,7,10,14-18)$.

During a sanitary selection program in northern Italy, several candidate clones of $V$. vinifera cultivars carrying infectious agents that induce RW phenomena were found (12; R. Credi, unpublished data). Appropriate biological indexing tests were carried out on the diseased material available to better characterize the wood abnormalities. Some preliminary results with graft-transmissions were reported previously (11). This paper describes results that reveal the diversity and heterogeneity of indicator responses, which can be used to differentiate between the RW sources and as a basis for their classification.

\section{MATERIALS AND METHODS}

RW sources. The RW-affected grapevine materials used as inoculum sources were obtained from a foundation vineyard set up by the Dipartimento di Colture Arboree, University of Bologna, Italy. The vineyard was established over time by collecting several clones from a single mother vine selection from most of the local $V$. vinifera cultivars grown in Emilia Romagna. All original mother vines and daughter clones were inspected repeatedly in the field for symptoms of virus and virus-like diseases. Most of them also had undergone standard indexing procedures (12; R. Credi, unpublished data). Over time, many clones were affected by RW and, therefore, were selected for the current differential indexing trials (Table 1).

Graft-inoculation on RW indicators. The selected RW-affected clones were used as budwood to graft-inoculate healthy indicator cvs. St. George, LN 33, and Kober $5 \mathrm{BB}$, originally obtained from A. C. Goheen, University of California, Davis. Buds from a virus-free, heat-treated clone that was negative for RW and other infectious diseases were used as controls. Trials were carried out from 1988 onward. Dormant canes of indicator vines were collected during the winter, and three bud cuttings (30 to $40 \mathrm{~cm}$ long) were inoculated with RW donor vines, using the chip-budding technique (16). Graft combinations were stratified in sawdust in boxes and callused in a heated room (approximately $30^{\circ} \mathrm{C}$ for the first 4 to 5 days and 25 to $27^{\circ} \mathrm{C}$ for an additional 15 days) at 80 to $90 \%$ relative humidity. Subsequently, the callusing boxes were placed in an unheated room (approximately 15 to $20^{\circ} \mathrm{C}$ ) for another 10 days, and after waxing, the indicator plants were potted and maintained in a glasshouse at temperatures ranging from 15 to $27^{\circ} \mathrm{C}$ until the following fall. During this period, the growing inoculated buds were periodically pruned back to prevent subsequent growth. Finally, during the following winter, successfully rooted and grafted vines were transplanted to a field nursery in rows with 50 $\mathrm{cm}$ between each plant and an interrow spacing of $200 \mathrm{~cm}$, using standard cultivation practices.

Indicator vines subsequently were evaluated for virus and virus-like diseases during the growing season. Final inspections of surviving vines for RW symptoms were made 3 or 4 years after grafting. During the spring, individual vines were uprooted and examined for alterations of the woody cylinder after removing the stem bark. Symptom severity was classed as weak (+), moderate $(++)$, and strong $(+++)$.

Virus testing. All selected RW sources were assayed serologically for the presence of the following phloem-limited viruses: grapevine leafroll-associated closteroviruses 1, 2, 3, and 5 (GLRaV-1, 2, 3, and 5) (4); grapevine trichovirus A (GVA) $(2,10)$; and grapevine fleck virus $(\mathrm{GFkV})(3,5)$. Grapevine fanleaf (GFLV) and arabis mosaic nepovirus (ArMV) tests also were performed. A conventional double-antibody sandwich enzyme-linked immunosorbent assay (DASELISA) (9) was used for GLRaV-1, GLRaV3, GFLV, and ArMV, with coating and conjugate antibody preparations purchased from Sanofi Diagnostics Pasteur (Marnes-La-Coquette, France), Bioreba Ag (Basel, Switzerland), and Agritest (Valenzano, Italy). Biotin DAS-ELISA was used for GLRaV-2 and 5, using kits also prepared by Sanofi Diagnostics. The presence of GVA and GFkV 
in grapevine samples was assayed with polyclonal and enzyme-conjugated monoclonal antibodies from Agritest. The antibody-trapped antigen forms of ELISA were used, following protocols developed by Boscia et al. (2,3). All the ELISA tests were performed following the manufacturer's instructions, with a few modifications. Duplicate samples were collected from each RW donor vine for at least two consecutive years. Samples of bark scrapings of dormant canes were prepared, frozen in liquid nitrogen, ground with a pestle and mortar, mixed in extraction buffer (0.2 M Tris- $\mathrm{HCl}, \mathrm{pH} 8.2$, containing $0.8 \%$ $\mathrm{NaCl}, 2 \%$ polyvinylpyrrolidone, and $0.05 \%$ Tween 20) with a ratio of $1: 10$ to $1: 15$ (wt/vol), and ground again. The extracts were filtered and incubated $(0.2 \mathrm{ml}$ per well) in duplicate wells on micro-ELISA plates (Dynatech Co. Inc., Alexandria, VA). Samples of virus-free grapevine tissues were added to each plate as negative controls. Optical absorbance at $405 \mathrm{~nm}$ was measured with an ELISA reader (Dynatech). Values three times higher than the mean of the healthy controls $(0.03)$ and equal to or greater than 0.10 were considered positive. Samples with absorbance values close to the positive-negative threshold were tested again.

\section{RESULTS}

The results of the differential indexing trials and ELISA carried out with 27 RWaffected clonal selections are summarized in Tables 2 through 6.

Reaction of indicator vines. All the selected RW inoculum sources induced stem pitting or grooving when graft-inoculated onto Vitis indicators. In contrast, no wood abnormalities were observed on control vines. Graft-transmission efficiency varied from 30 to $100 \%$. On the basis of indicator reactivity, individual RW sources were classified into diverse host-range groups. Nine RW-affected clones caused symptoms exclusively on cv. St. George (Table 2). The stem reaction associated with clones BL11A, CN09, CN015, RSS6, and TRCV1 varied in severity from weak to strong and consisted of a row of pits that developed downward from the point of inoculation (Fig. 1A). The other clones (BL1, LS3, PGD2, and TRCV4) induced similar symptoms. Pittings, however, were distributed wherever the trunk was exposed. Four clones (ALZ1A, BL13, MS6, and MS7) induced wood symptoms only on cv. Kober 5BB indicator plants (Table 3). Stem reactions on graft-inoculated vines generally had a mixed expression, ranging from moderate to strong, of pitting and grooving, systematically distributed in the woody cylinder (Fig. 1B). More than one indicator cultivar reacted positively with the rest of the RW inoculum sources. Three affected clones (AL19, TR12, and TSC1) induced symptoms on vines of cvs. LN 33 and Kober 5BB (Table 4). Most of the inoculated vines showed strong stem grooving (Fig. 1C), but the bark appeared normal. Seven clones (BR17C, CG18, LGR4A, LGR9, LO9, LS12G, and LSB4) induced a positive RW reaction, of moderate to strong severity, on cvs. St. George and Kober 5BB (Table 5; Fig. 1D). Of these, LSB4, BR17C, and LGR9 also caused suberification of the stem cortex of cv. Kober 5BB vines. Finally, four clones (LGR4B, LGR5, LGR7, and LGR30G) induced RW in vines of all three indicators (Table 6). Recipient cv. LN 33 vines also expressed abnormally thick and corky stem bark (Fig. 1E and F).

Virus detection in RW inoculum sources. The results of ELISA indicated

Table 1. Selected clones of Vitis vinifera cultivars used as rugose wood (RW) disease inoculum sources in graft-transmission trials and their complete infectious disease status

\begin{tabular}{lll}
\hline Cultivar & Clone & \multicolumn{1}{c}{ Sanitary status } \\
\hline Albana & AL19 & RW + LR + VN + FK \\
Alionza & ALZ1A & RW + LR + VN \\
Biancale & BL1 & RW + VM \\
Biancale & BL11A & RW + VN + FK \\
Biancale & BL13 & RW + LR + VM + FK \\
Brugnola & BR17C & RW + LR \\
Canino & CNO9 & RW + LR + VN + FK \\
Canino & CNO15 & RW + LR + VN \\
Cargarello & CG18 & RW + LR + VN \\
Lambrusco & LS3 & RW + VN + VM \\
Lambrusco & LGR4A & RW + LR + VM \\
Lambrusco & LGR9 & RW + LR + VM \\
Lambrusco & LO9 & RW + VN + VM \\
Lambrusco & RS12G & RW + VN + VM \\
Lambrusco & LSB4 & RW + LR + VM \\
Lambrusco & LGR4B & RW + LR + VM \\
Lambrusco & LGR5 & RW + LR + VM \\
Lambrusco & LGR7 & RW + LR + VN+FK \\
Lambrusco & LGR30G & RW + LR + FK \\
Moscato & MS6 & RW + LR + VN \\
Moscato & MS7 & RW + VN + VM \\
Pagadebit & RGD2 & RW + VM \\
Rossiola & RSS6 & RW + LR + VN + VM + VM \\
Tosca & TSC1 & RW + VN \\
Trebbiano & TR12 & RW + LR + VN + VM \\
Trebbiano & TRCV1 & TRCV4 \\
Trebbiano & T &
\end{tabular}

a Grapevine virus and virus-like diseases according to previous biological indexing and field observations: $\mathrm{RW}=$ rugose wood, $\mathrm{LR}=$ leafroll, $\mathrm{VN}=$ vein necrosis, $\mathrm{VM}=$ vein mosaic, and $\mathrm{FK}=$ fleck.

Table 2. Response of Vitis indicators to graft-inoculation with affected clones that induced rugose wood (RW) disease stem symptoms only on cv. St. George, which, therefore, were classifiable as isolates of rupestris stem pitting disease, and their enzyme-linked immunosorbent assay (ELISA) reactivity

\begin{tabular}{lclcc}
\hline \multirow{2}{*}{$\begin{array}{l}\text { RW inoculum } \\
\text { source clone }\end{array}$} & $\begin{array}{c}\text { ELISA } \\
\text { reactivity }\end{array}$ & St. George & LN 33 & Kober 5BB $^{\text {Indicator vine }} \mathbf{b}^{\mathbf{b}}$ \\
\cline { 4 - 5 } BL1 & - & $++(5 / 5)$ & $-(0 / 9)$ & $-(0 / 33)$ \\
BL11A & GLRaV-1, GFkV & $++(13 / 17)$ & $-(0 / 16)$ & $-(0 / 35)$ \\
CNO9 & GLRaV-3, GFkV & $++(20 / 26)$ & $-(0 / 9)$ & $-(0 / 30)$ \\
CNO15 & GLRaV-1, GLRaV-3 & $+(6 / 13)$ & $-(0 / 10)$ & $-(0 / 5)$ \\
LS3 & - & $+++(20 / 31)$ & $-(0 / 18)$ & $-(0 / 34)$ \\
PGD2 & - & $++(4 / 12)$ & $-(0 / 2)$ & $-(0 / 3)$ \\
RSS6 & - & $+++(7 / 14)$ & $-(0 / 21)$ & $-(0 / 25)$ \\
TRCV1 & - & $+(13 / 17)$ & $-(0 / 31)$ & $-(0 / 26)$ \\
TRCV4 & GLRaV-1 & $++(4 / 10)$ & $-(0 / 19)$ & $-(0 / 10)$ \\
\hline
\end{tabular}

a Virus infections: GLRaV-1 and $3=$ grapevine leafroll-associated virus 1 and 3 and GFkV = grapevine fleck virus; - indicates the clone was rated negative for virus.

${ }^{\mathrm{b}}$ Average rating of stem symptom severity:,+++ , and +++ indicate vines showing mild, medium, and strong symptoms, respectively; - indicates no symptoms observed. The number of vines with positive stem reactions per number of graft-inoculated vines are shown in parentheses. 


\section{DISCUSSION}

The results obtained with the current graft-transmission trials support previous findings on the possibility of distinguishing single disease components of the grapevine RW complex $(13,15,16,19)$. Five host-range groups based on the RW inoculum sources used in the study were identified by indexing on the proper differential Vitis indicators. Some of RW-affected clones induced symptoms on all three indicator cultivars and the others on only one or two cultivars. A number of the isolates from selected RW sources caused stem pitting exclusively on V. rupestris cv. St. George (Table 2). These appear to correspond with the RSP syndrome $(15,16)$. The symptomatic expression of RSP is reported to have a basipetal localized distribution in the woody cylin- der when indicator vines are inoculated by chip-budding. However, about half of these isolates produced pits all over the stem. One possible explanation is the existence in nature of different RSP pathotypes. Moreover, the investigation clearly indicated that some of the selected RW inoculum sources should be classified as KSG $(16,19)$, inducing stem grooving only on cv. Kober 5BB (Table 3). None of the inocula were definitely shown to contain the single presence of LNSG $(13,16)$. However, the majority of the RW-affected clones tested showed different probable combinations of these three single RW diseases.

Based on the indexing results, the RW sources grouped in Table 4 may have been affected by both LNSG and KSG. The inoculum sources grouped in Table 5 may

Table 3. Response of Vitis indicators to graft-inoculation with affected clones that induced rugose wood (RW) disease stem symptoms only on cv. Kober 5BB, which, therefore, were classifiable as isolates of Kober stem grooving disease, and their enzyme-linked immunosorbent assay (ELISA) reactivity

\begin{tabular}{lllll}
\hline \multirow{2}{*}{$\begin{array}{l}\text { RW inoculum } \\
\text { source clone }\end{array}$} & \multicolumn{1}{c}{$\begin{array}{c}\text { ELISA } \\
\text { reactivity }\end{array}$} & \multicolumn{3}{c}{ Indicator vine $^{\mathbf{b}}$} \\
\cline { 2 - 4 } & St. George & LN 33 & Kober 5BB \\
\hline ALZ1A & GLRaV-3, GVA & $-(0 / 18)$ & $-(0 / 15)$ & $+++(34 / 35)$ \\
BL13 & GLRaV-1, GVA, GFkV & $-(0 / 10)$ & $-(0 / 15)$ & $++(12 / 15)$ \\
MS6 & GLRaV-1, GVA, GFkV & $-(0 / 12)$ & $-(0 / 3)$ & $++(2 / 5)$ \\
MS7 & GLRaV-1, GVA & $-(0 / 8)$ & $-(0 / 7)$ & $+++(8 / 9)$ \\
\hline
\end{tabular}

a Virus infections: GLRaV-1 and 3 = grapevine leafroll-associated virus 1 and 3, GVA = grapevine trichovirus $\mathrm{A}$, and $\mathrm{GFkV}=$ grapevine fleck virus.

${ }^{\mathrm{b}}$ Average rating of stem symptom severity: ++ and +++ indicate vines showing medium and strong symptoms, respectively; - indicates no symptoms observed. The number of vines with positive stem reactions per number of graft-inoculated vines are shown in parentheses.

Table 4. Response of Vitis indicators to graft-inoculation with affected clones that induced rugose wood (RW) disease stem symptoms on cvs. LN 33 and Kober 5BB and their enzyme-linked immunosorbent assay (ELISA) reactivity

\begin{tabular}{llccl}
\hline \multirow{2}{*}{$\begin{array}{l}\text { RW inoculum } \\
\text { source clone }\end{array}$} & $\begin{array}{c}\text { ELISA } \\
\text { reactivity }\end{array}$ & \multicolumn{3}{c}{ Indicator vine $^{\mathbf{b}}$} \\
\cline { 2 - 4 } & GLRaV-1, GVA, GFkV & $-(0 / 15)$ & $++(11 / 21)$ & $+++(16 / 16)$ \\
AL19 & GLRaV-1, GVA & $-(0 / 17)$ & $+++(9 / 12)$ & $+++(21 / 29)$ \\
TR12 & GLRaV-1, GVA & $-(0 / 10)$ & $+++(3 / 10)$ & $+++(9 / 11)$ \\
\hline TSC1 & &
\end{tabular}

a Virus infections: GLRaV-1 = grapevine leafroll-associated virus 1, GVA = grapevine trichovirus A, and GFkV = grapevine fleck virus.

${ }^{\mathrm{b}}$ Average rating of stem symptom severity: ++ and +++ indicate vines showing medium and strong symptoms, respectively; - indicates no symptoms observed. The number of vines with positive stem reactions per number of graft-inoculated vines are shown in parentheses.

Table 5. Response of Vitis indicators to graft-inoculation with affected clones that induced rugose wood (RW) disease stem symptoms on cvs. St. George and Kober 5BB and their enzyme-linked immunosorbent assay (ELISA) reactivity

\begin{tabular}{lllll}
\hline \multirow{2}{*}{$\begin{array}{l}\text { RW inoculum } \\
\text { source clone }\end{array}$} & \multicolumn{1}{c}{$\begin{array}{c}\text { ELISA } \\
\text { reactivity }\end{array}$} & St. George & LN 33 & Kober 5BB $^{\text {Indicator vine }^{\mathbf{b}}}$ \\
\cline { 2 - 5 } BR17C & GLRaV-1, GLRaV-3, GVA & $++(3 / 6)$ & $-(0 / 7)$ & $+++(13 / 16)$ \\
CG18 & GLRaV-3, GVA & $++(17 / 28)$ & $-(0 / 23)$ & $++(24 / 35)$ \\
LGR4A & GLRaV-1, GVA & $+++(11 / 13)$ & $-(0 / 8)$ & $+++(6 / 6)$ \\
LGR9 & GLRaV-1, GVA & $++(12 / 18)$ & $-(0 / 5)$ & $+++(12 / 14)$ \\
LO9 & - & $+++(19 / 21)$ & $-(0 / 23)$ & $+++(21 / 37)$ \\
LS12G & - & $+++(19 / 19)$ & $-(0 / 5)$ & $+++(5 / 11)$ \\
LSB4 & - & $+++(4 / 8)$ & $-(0 / 11)$ & $++(32 / 37)$ \\
\hline
\end{tabular}

a Virus infections: GLRaV-1 and $3=$ grapevine leafroll-associated virus 1 and 3 and GVA = grapevine trichovirus $\mathrm{A} ;-$ indicates the clone was rated negative for viruses.

${ }^{b}$ Average rating of stem symptom severity: ++ and +++ indicate vines showing medium and strong symptoms, respectively; - indicates no symptoms observed. The number of vines with positive stem reactions per number of graft-inoculated vines are shown in parentheses.

have contained a combination of RSP and KSG, whereas those in Table 6 may have contained a combination of RSP, LNSG, and KSG. These last two groups of isolates, however, induced a reaction characterized by strong grooving, systemically distributed, in cv. St. George stems that was not typical of the RSP disease. A possible synergistic effect of various causal pathogenic agents can be suggested. CB disease, another component of the grapevine RW complex, also is reported to induce severe stem grooving and pitting in cvs. St. George and LN $33(15,16)$. However, this hostrange pattern (Table 6) was not accompanied by the typical leaf and cane symptoms usually associated with $\mathrm{CB}$ on $\mathrm{cv}$. $\mathrm{LN}$ 33. Indicator vines only showed rolling and reddening of leaves, which is characteristic of leafroll disease (16). Consequently, the occurrence of $\mathrm{CB}$ disease has not been demonstrated.

Generally speaking, the interpretation given for the RW phenomena described here are very tentative due to the numerous complex factors involved. For instance, the causal agents for the individual RW syndromes are still unidentified. The possible influence on their expression of associated virus and virus-like infections (Table 1) also is still unknown. Moreover, woody indexing tests may not be completely reliable, because results can be affected by various elements. For example, a possible latency of these wood disorders must be considered, as has been suggested previously (20). This also would explain the low grafttransmission efficiency in some groups of inoculated indicator vines.

The results of the ELISA tests indicated the virological status of the inoculum sources and made it possible to analyze the relationship between the presence of GLRaV-1 and 3, GVA, and GFkV and the RW symptoms found. However, other grapevine leafroll-associated closterovirus infections may have been present. For example, the possible occurrence of GLRaV-4, 6 (4), and 7 (8) was not investigated. GLRaV-1 and 3 are considered the most important etiological agents of grapevine leafroll disease $(4,16)$. GFkV is the causal agent of fleck disease $(3,5)$. The presence of these viruses usually was consistent with the infectious disease status of the selected RW-affected clones, previously ascertained by traditional indexing procedures and field observations (Table 1) or determined during these trials. GVA infection reportedly is linked to the KSG wood disorder $(7,14)$. The present investigation seems to confirm these findings. GVA was not found among RSP isolates (Table 2), whereas all the KSG isolates contained this virus (Table 3). GVA also was detected in almost all the remaining RW sources, possibly containing the multiple presence of KSG with other RW single components. The exception was represented by three isolates that did not have any virus infection (Table 5). These, along with the 
RSP isolates also rated ELISA-negative (Table 2), could be potential pure disease sources. The data confirmed the etiological complexity of the RW phenomena occurring in grapevine. In an attempt to elucidate the phenomena, the possible occur- rence of grapevine trichovirus $\mathrm{B}$, reported by Boscia et al. (6), which is thought to play a key role in the CB syndrome, grapevine trichovirus $\mathrm{C}$, reported by Monette and James (18), and grapevine trichovirus $\mathrm{D}$, recently isolated by Abou-Ghanem et

Table 6. Response of Vitis indicators to graft-inoculation with affected clones that induced rugose wood (RW) disease stem symptoms on cvs. St. George, LN 33, and Kober 5BB and their enzyme-linked immunosorbent assay (ELISA) reactivity

\begin{tabular}{lllll}
\hline \multirow{2}{*}{$\begin{array}{l}\text { RW inoculum } \\
\text { source clone }\end{array}$} & \multicolumn{1}{c}{$\begin{array}{c}\text { ELISA } \\
\text { reactivity }\end{array}$} & St. George & LN 33 & Kober 5BB \\
\cline { 4 - 5 } LGR4B & GLRaV-1, GVA & $+++(21 / 24)$ & $++(14 / 27)$ & $+++(17 / 21)$ \\
LGR5 & GLRaV-1, GVA & $++(14 / 25)$ & $+++(18 / 21)$ & $+++(24 / 28)$ \\
LGR7 & GLRaV-1, GVA & $+++(15 / 19)$ & $++(1 / 1)$ & $+++(2 / 2)$ \\
LGR30G & GLRaV-1, GVA & $++(8 / 25)$ & $++(9 / 9)$ & $+++(32 / 32)$ \\
\hline
\end{tabular}

a Virus infections: GLRaV-1 = grapevine leafroll-associated virus 1 and GVA = grapevine trichovirus A.

b Average rating of stem symptom severity: ++ and +++ indicate vines showing medium and strong symptoms, respectively The number of vines with positive stem reactions per number of graft-inoculated vines are shown in parentheses.
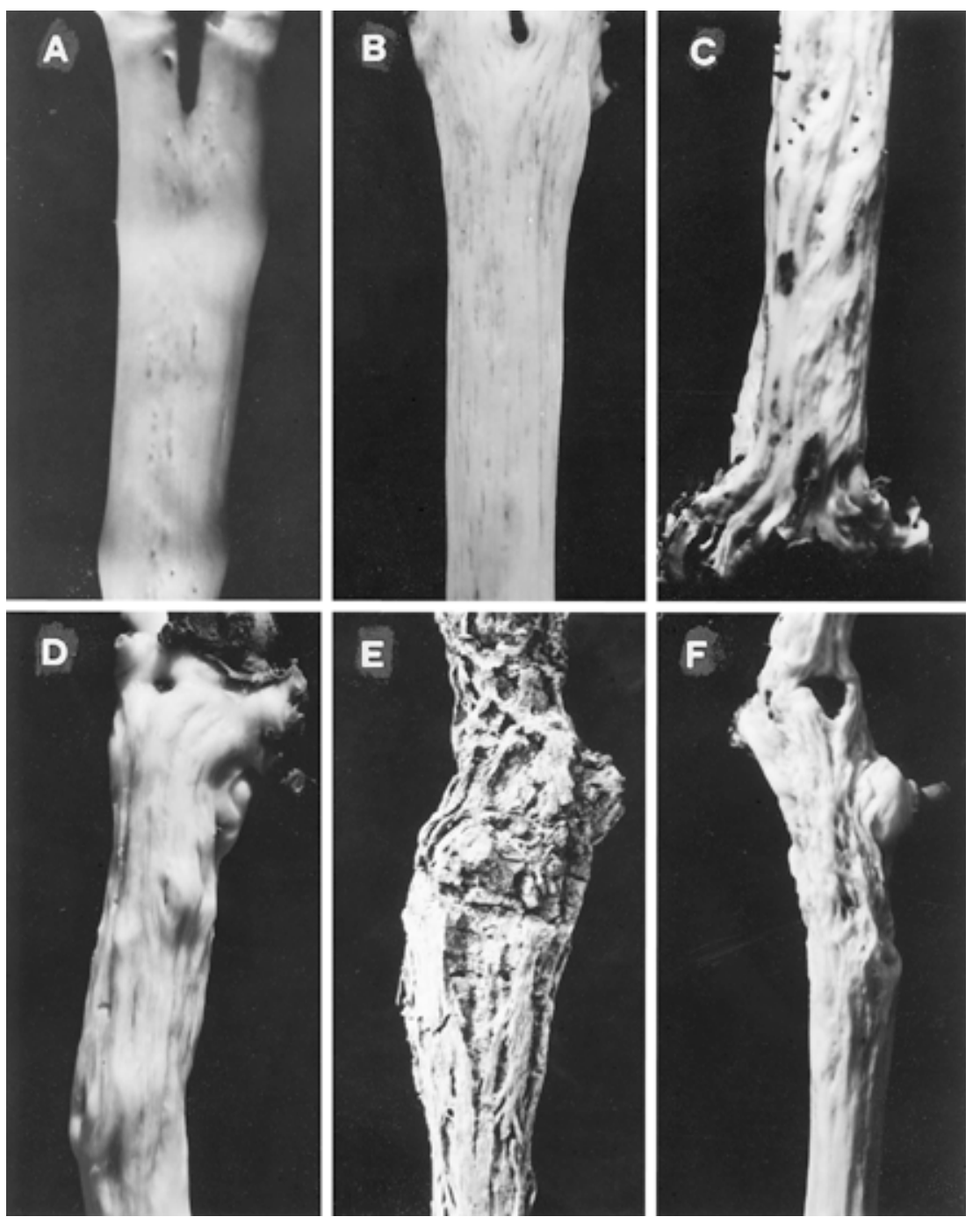

Fig. 1. Differential stem reaction of Vitis indicator plants to graft-inoculation with affected clones from selected grapevine rugose wood (RW) disease sources. (A) Symptoms of rupestris stem pitting (RSP) on cv. St. George induced by clone CN09. (B) Symptoms of Kober stem grooving (KSG) on cv. Kober 5BB induced by clone ALZ1A. (C) Symptoms on indicator cv. LN 33 induced by clone TR12, with a possible association of LN 33 stem grooving (LNSG) and KSG. (D) Symptoms on indicator cv. St. George induced by clone LGR4A, with a possible association of RSP and KSG. (E) Trunk of indicator cv. LN 33 showing corky bark and (F) after exposure, grooving of the woody cylinder induced by clone LGR30G, with a possible association of RSP, LNSG, and KSG diseases.

al. (1), must be investigated further. The possible existence of other filamentous virus particles, distinct from those previously described (17), also should be considered.

In conclusion, the collection of grapevine RW isolates, representing the diversity of types occurring naturally in a typical viticultural region, is an important resource and will be invaluable in future fundamental etiological studies.

\section{ACKNOWLEDGMENTS}

This study was funded by ESAVE (Ente per gli Studi e l'Assistenza Viticola ed Enologica dell'Emilia Romagna). I thank C. Intrieri (Dipartimento di Colture Arboree, University of Bologna, Italy) for providing the budwood of diseased clones used as inoculum sources.

\section{LITERATURE CITED}

1. Abou Ghanem, N., Saldarelli, P., Minafra, A. Castellano, M. A., and Martelli, G. P. 1997. Properties of grapevine virus D, a novel putative trichovirus. J. Plant Pathol. 78:15-25.

2. Boscia, D., Aslouj, E., Elicio, V., Savino, V., Castellano, M. A., and Martelli, G. P. 1992. Production characterization and use of monoclonal antibodies to grapevine virus A. Arch. Virol. 127:185-194.

3. Boscia, D., Elicio, V., Savino, V., and Martelli, G. P. 1995. Production of monoclonal antibodies to grapevine fleck virus. Plant Pathol. 44:160-163.

4. Boscia, D., Greif, C., Gugerli, P., Martelli, G. P., Walter, B., and Gonsalves, D. 1995. Nomenclature of grapevine leafroll-associated putative closteroviruses. Vitis 34:171-175.

5. Boscia, D., Martelli, G. P., Savino, V., and Castellano, M. A. 1991. Identification of the agent of grapevine fleck disease. Vitis 30:97105.

6. Boscia, D., Savino, V., Minafra, A., Namba, S. Elicio, V., Castellano, M. A., Gonsalves, D. and Martelli, G. P. 1993. Properties of a filamentous virus isolated from grapevines affected by corky bark. Arch. Virol. 130:109-120.

7. Chevalier, S., Greif, C., Clauzel, J. M., Walter, B., and Fritsch, C. 1995. Use of an immunocapture-polymerase chain reaction procedure for the detection of grapevine virus A in Kober stem grooving-infected grapevines. J. Phytopathol. 143:369-373.

8. Choueiri, E., Boscia, D., Digiaro, M., Castellano, M. A., and Martelli, G. P. 1996. Some properties of a hitherto undescribed filamentous virus of the grapevine. Vitis 35:91-93.

9. Clark, M. F., and Adams, A. N. 1977. Characteristics of the microplate method of enzymelinked immunosorbent assay for the detection of plant viruses. J. Gen. Virol. 34:475-483.

10. Conti, M., Milne, R. G., Luisoni, E., and Boccardo, G. 1980. A closterovirus from a stem-pitting-diseased grapevine. Phytopathology 70:394-399.

11. Credi, R. 1993. Differential indexing trials on grapevine rugose wood syndromes. Page 63 in: Ext. Abstr. 11th Meet. ICVG. P. Gugerli, ed. Federal Agricultural Research Station of Chaupins, Nyon, Switzerland.

12. Credi, R., and Babini, A. R. 1987. Miglioramento sanitario della vite ed incidenza di alcune malattie da virus e virus-simili nelle regioni dell'Emilia-Romagna e Piemonte. Schweiz. Landow. Fo./Rech. Agron. Suisse 26:328-331.

13. Garau, R., Prota, U., and Cugusi, M. 1989 Investigations on wood disorders (stem pitting and/or stem grooving) of grapevine in Sardinia. Pages 135-141 in: Proceedings of the 9th Meeting of ICVG, Kiryat Anavim, Israel. 
14. Garau, R., Prota, V. A., Piredda, R., Boscia, D., and Prota, U. 1994. On the possible relationship between Kober stem grooving and grapevine virus A. Vitis 33:161-163.

15. Goheen, A. C. 1988. Corky bark, rupestris stem pitting. Pages 52-53 in: Compendium of Grape Diseases. R. C. Pearson and A. C. Goheen, eds. The American Phytopathological Society, St. Paul, MN.

16. Martelli, G. P., ed. 1993. Graft-Transmissible
Diseases of Grapevines. Handbook for Detection and Diagnosis. FAO, Rome.

17. Monette, P. L., and Godkin, S. E. 1995. Detection of capillovirus-like particles in a grapevine affected with rugose wood. Vitis 34:241242.

18. Monette, P. L., and James, D. 1991. Detection of a closteroviruslike particle from a corky bark-affected grapevine cultivar. Vitis 30:3743.
19. Savino, V., Boscia, D., and Martelli, G. P. 1989. Rugose wood complex of grapevine: Can grafting to Vitis indicators discriminate between diseases? Pages 91-94 in: Proceedings of the 9th Meeting of ICVG, Kiryat Anavim, Israel.

20. Savino, V., Boscia, D., Musci, D., and Martelli, G. P. 1985. Effect of legno riccio (stem pitting) on 'Italia' vines grafted onto rootstocks of different origin. Phytopathol. Mediter. 24: 68-72. 